\title{
КИПРСКАЯ ПРАВОСЛАВНАЯ ЦЕРКОВЬ И БОРЬБА ЗА ЭНОЗИС В 1900-1925 ГГ. (ПО АРХИВНЫМ МАТЕРИАЛАМ МИНИСТЕРСТВА ИНОСТРАННЫХ ДЕЛ ГРЕЦИИ)
}

\author{
К. Ю. Артамонова
}

\begin{abstract}
Артамонова К. Ю. Кіпрська православна церква і боротьба за енозис в 1900-1925 рр. (за архівними матеріалами Міністерства закордонних справ Греції). У статті зроблена спроба простежити взаємини кіпрського православного духовенства і грецького уряду з питання приєднання острова Кіпр до Греції за часів британського правління. Простежується стадіальність розвитку політики енозиса як з боку грецьких політиків, так і з боку кіпрських архієпископів, обумовлену внутрішнім політичним розколом на Кіпрі та в Греції. Автор приходить до висновку, що пропозиція Великої Британії віддати Кіпр Греції в 1915 р. в обмін на вступ країни у війну була єдиною можливістю Афін придбати острів дипломатичним шляхом, яку країна згаяла. Наступні спроби Архієпископа Кіпрського Кирила III та прем’єр-міністра Греції Е. Венізелоса домогтися від британської влади здійснення енозиса не мали успіху.
\end{abstract}

Ключові слова: Кіпрська православна церква; уряд Королівства Греція; грецьке консульство на Кіпрі; енозіс.

Артамонова К. Ю. Кипрская православная церковь и борьба за энозис в 1900-1925 гг. (по архивным материалам Министерства иностранных дел Греции). В статье предпринята попытка проследить взаимоотношения кипрского православного духовенства и греческого правительства по вопросу присоединения острова Кипр к Греции во времена британского правления. Прослеживается стадиальность развития политики энозиса как со стороны греческих политиков, так и со стороны кипрских архиепископов, обусловленная внутренним политическим расколом на Кипре и в Греции. Автор приходит к выводу, что предложение Великобритании отдать Кипр Греции в 1915 г. в обмен на вступление страны в войну было единственным шансом Афин приобрести остров дипломатическим путем, который страна упустила. Последующие попытки Архиепископа Кипрского Кирилла III и премьер-министра Греции Э. Венизелоса добиться от британских властей осуществления энозиса не увенчались успехом.

Ключевые слова: Кипрская православная церковь; правительство Королевства Греция; греческое консульство на Кипре; энозис.

Artamonova K. Y. The Orthodox Church of Cyprus and the struggle for enosis during 1900-1925 (according to the materials of Archive of the Ministry of Foreign Affairs of Greece). The article attempts to trace the relations between the Cyprus Orthodox clergy and the Greek government on the issue of accession of Cyprus to Greece during the British rule. It traces enosis policy evolution by stages both on the part Greek politicians and by the Archbishops of Cyprus, due to internal political split in Cyprus and Greece. The author concludes that the Great Britain proposal to give Cyprus to Greece in 1915 in exchange for the country's entry into the war was the only chance of Athens to purchase the island through diplomatic channels that the country missed. Subsequent attempts by the Archbishop of Cyprus Cyril III and Greek Prime Minister E.Venizelos to achieve the enosis by the British authorities failed.

Keywords: Orthodox Church of Cyprus; government of the Kingdom of Greece; Greek Consulate in Cyprus; enosis.

Островное положение Кипра, давняя автокефалия Кипрской православной церкви (КПЦ) и колониальный статус страны на протяжении четырехсот лет повлияли на складывание особой роли православной церкви в кипрском обществе. Во время османского господства КПЦ обладала административными функциями по отношению к православным грекам, составлявшим большую часть кипрского населения, а также была выразителем их интересов. При этом КПЦ считала себя неотъемлемой частью большого православного византийского мира и ставила своей основной задачей воссоединение Кипра с греческим миром, что в дальнейшем воплотилось в идею энозиса.

Идея энозиса (в переводе с греческого - «союз, единство») зародилась в период национально-освободительной войны греков против Османской империи. Появление в феврале 1830 г. суверенного Королевства Греция повлияло на развитие национальных идей в многонациональной империи. Среди ее греческих подданных распространялась идея 
энозиса, суть которой состояла в освобождении всех греческих земель от османского владычества и их присоединении к Королевству Греция. Часть греческих революционеров шла дальше, объявив о необходимости восстановления единого греческого государства в территориальных рамках бывшей Византийской империи. Данное течение оформилось в т.н. «Мегали идею», ставшую популярной на территории Балканского полуострова в период национально-освободительных войн местных народов против османского владычества. Идея энозиса больше всего сторонников обрела на Кипре, где церковь возглавила борьбу за воссоединение острова с Грецией.

Роль КПЦ в национально-освободительном движении греков-киприотов рассматривалась в исследованиях Дж. Хилла ${ }^{1}$, В. Энглезакиса ${ }^{2}$, А. Виттиса ${ }^{3}$, Т. Пападопулоса ${ }^{4}$, Х. Икономидиса $^{5}$, А. Варнава, М. Михаела ${ }^{6}$, К. Коккинофтаса ${ }^{7}$. При исследовании данного вопроса ими практически не рассматривались материалы греческого вице-консульства на острове. В данной работе предпринята попытка отразить идею энозиса в деятельности КПЦ, основываясь именно на материалах Министерства иностранных дел Греции, которые к тому же позволяют судить о политике греческого правительства в этом вопросе. С этой целью нами изучены переписка греческого вице-консульства на Кипре с 1900 по 1925 гг., а также материалы периодической печати и внутренние документы КПЦ, которые передавались через консульские органы греческому правительству для ознакомления с общественно-политической ситуацией на Кипре в период британского правления.

С приходом на остров англичан в 1878 г. церковь стала лидером общественно-политической жизни, представляя интересы греков-киприотов перед новыми властями на острове и за его пределами. Начались активные контакты КПЦ с греческим правительством. Афины считали остров исконно своей территорией и в рамках «Мегали идеи» рассматривали возможность присоединения Кипра к Греции. Кипрская проблема играла важную роль во внешней политики Греции, о чем можно судить по депешам греческих консулов из Ларнаки и Никосии ${ }^{8}$. Первое греческое вице-консульство было основано в Ларнаке в 1833 г.; в 1917 г. оно получило статус Генерального и было перенесено в Никосию9.

К началу XX века Кипрская православная церковь пережила череду кризисов. Обострились отношения с британскими властями, осуществлявшими политику по принципу «разделяй и властвуй», что приводило к столкновениям интересов церкви и английской администрации. В 1898 г. умер митрополит Пафсский Епифаний, два года спустя, не успев принять участие в выборах нового митрополита Пафоса, умирает Архиепископ Кипра Софроний. Во главе Кипрской церкви осталось два правящих иерарха - митрополит Китиона Кирилл Пападопулос и митрополит Керинии Кирилл Василиосс ${ }^{10}$, претендовавшие на архиепископский престол. По причине отсутствия в Кипрской церкви механизма выбора архиепископа между митрополитами разгорелась борьба за трон, приведшая к политическому расколу острова на два лагеря: «китионцев», поддерживавших митрпополита Китиона, и «керинийцев»- сторонников митрополита Керинии ${ }^{11}$. В греческой литературе того времени использовались прозвища митрополитов, возникшие в народе: митрополита Китионского Кирилла называли «Кирилл-большой», а митрополита Керинийского - «Кирилл-малый», руководствуясь их внешними и возрастными отличиями.

Конфликт, разгоревшийся в 1900 г., был не только церковным, но и внутриполитическим. Каждый из митрополитов представлял одно из двух политических течений на острове, видевших по-разному решение национального вопроса. Митрополит Кирилл Китионский был сторонником бескомпромиссного требования энозиса, решительного давления на английское правительство, чтобы достичь немедленного объединения Кипра с Грецией. Митрополит Кирилл Керинийский представлял те слои населения, которые поддерживали умеренную политику в отношении англичан и рассматривали энозис в качестве долгосрочной перспективы ${ }^{12}$. Конфликт двух Кириллов вышел далеко за пределы острова; к его разрешению приобщились патриархи Константинополя, Иерусалима, Александрии, а также вице-консульство Греческого Королевства на Кипре.

Константинопольский патриарх Иоаким III активно поддерживал митрополита Керинии Кирилла Василиоса. В частности, патриарх настаивал на том, что большая часть населения не хотела видеть митрополита Китиона в качестве главы Кипрской церкви, а британская администрация, по его словам, характеризовала последнего как «мятежника» 13 . Британское же посольство в Константинополе полагало, что вмешательство Вселенского патриарха нарушает права автокефальной Кипрской церкви ${ }^{14}$. 
МИД Греции внимательно следил за развитием кипрского церковно-политического конфликта и его резонансом в православном мире. Архивные материалы по Кипру за 1902-1903 гг. вынесены в отдельный том и содержат различные документы, которые разделены на три основных блока.

Первый блок составляет переписка митрополита Китиона Кирилла с Верховным комиссаром Кипра, донесения греческого вице-консула о вмешательстве в проблему Константинопольской и Иерусалимской патриархий, подкрепленные материалами кипрской периодической печати. Так, в письме к министру иностранных дел Греции от 18 мая 1902 г. вице-консул пишет: «На прошлой неделе были получены две телеграммы от Их Блаженства Патриарха Константинопольского и Патриарха Иерусалимского, в которых они принимают кандидатуру митрополита Китионского в качестве нового (возможного - К. А.) Архиепископа, однако считают митрополита Керинии более подходящей кандидатурой на архиепископский престол, после него ставят кандидатуру господина Константинидиса (архимандрит Григорий Константинидис - К. А.), которого Их Блаженства оценивают как благородного человека» ${ }^{15}$. В том же письме вице-консул сообщает, что «народные представители не одобрили такое решение патриархов, а Верховный комиссар заявил депутатам, что правительство не может назначать экзархов Кипра» ${ }^{16}$.

Отдельно содержатся копии документов Иерусалимской патриархии, направленные в адрес митрополитов, и донесения греческого вице-консула, в которых содержатся размышления о прокеринийской позиции Патриарха Иерусалима Дамаскина ${ }^{17}$.

Следующий блок документов включает переписку Иерусалимского патриарха Дамаскина I с премьер-министром Греции А. Заимисом по вопросу архиепископского престолонаследия, а также корреспонденцию греческих консульств в Иерусалиме, Константинополе, Александрии. Главной темой консульских депеш в 1902-1903 гг., наряду с сообщениями о положении греческой диаспоры, состоянии школ и монастырей за пределами Греции, становится кипрская проблема ${ }^{18}$. Наконец, последний блок документов содержит переписку Иерусалимского патриарха Дамаскина I с Константинопольским Иоакимом III по разным вопросам ${ }^{19}$.

Такое пристальное внимание греческого Министерства иностранных дел к делам патриархий было вызвано диаметрально противоположной позицией высших церковных иерархов в кипрском вопросе. В ходе церковного конфликта на Кипре православный греческий мир, также как и на острове, раскололся на два лагеря. Греческое правительство вместе с Александрийским патриархом поддерживало бескомпромиссного сторонника энозиса митрополита Китиона Кирилла Пападопулоса, а Константинопольский и Иерусалимский патриархи - более умеренного митрополита Керинии Кирилла Василиоса.

1907 год стал поворотным в решение вопроса. Верховный комиссар Кипра Ч.Э. КингХарман подал в Законодательный совет законопроект «О выборах архиепископа», подготовка которого была возложена на светского политика Иоанниса Кирякидиса. Митрополит Керинии Кирилл отверг этот законопроект; кипрского иерарха поддержал Вселенский патриарх Иоаким III. В июне того же года на Кипр, для оказания помощи в разрешении кризиса, прибыли патриарх Александрийский Фотий, архимандрит Иерусалимского патриархата Мелетий Метаксакис и митрополит Анхиальский Василий, представлявший интересы Константинополя.

Перед визитом на Кипр и в ходе его Александрийский патриарх вел активную переписку с греческим правительством и его консульскими органами на острове, выдвигая митрополита Китиона Кирилла на пост Архиепископа Кипра как самую подходящую кандидатуру. Во время визита патриарха на остров фактически сложился альянс греческого вице-консульства и Александрийской патриархии в поддержку Китионского митрополи$\mathrm{Ta}^{20} .2$ октября 1907 г. в письме к министру иностранных дел Греции вице-консул встал на защиту митрополита Китиона в ответ на обвинения его в масонстве керинийцами ${ }^{21}$.

20 ноября греческий вице-консул Калутсис сообщал, что единственное желание британского правительства - признать нового архиепископа, когда пройдут его выборы согласно обычаю и традиции Кипрской православной церкви ${ }^{22}$, а 14 декабря 1907 г. греческое посольство в Константинополе сообщает министру иностранных дел о том, что патриарх Александрийский активно сотрудничает с митрополитом Китиона ${ }^{23}$.

Письма греческого вице-консула на Кипре за 1907 - начало 1908 г., обращенные к министру иностранных дел Греции, в основном посвящены приезду патриарха Фотия на 
Кипр, его встречам и переговорам с греческим консульством, попыткам давления Константинопольского патриарха на Синод КПЦ в выборе архиепископа при содействии Мелетия Метаксакиса и митрополита Анхиальского Василия.

В феврале 1908 г. Константинопольская патриархия приняла единоличное решение назначить новым Архиепископом Кипра митрополита Керинийского Кирилла. В ответ на такое решение Константинополя сторонники митрополита Китиона собрались в г. Никосии под греческими флагами, требуя избрать их кандидата. Керинийцы, тем временем, заняли Архиепископию, где на тот момент находились оба митрополита, и потребовали провести процесс интронизации Кирилла Василиоса. Ситуация настолько накалилась, что греческий вице-консул писал в министерство: «Очень большая вероятность того, что Кипрская церковь подвергнется схизме» ${ }^{24}$. Британские власти, дабы предотвратить кровопролитие, эвакуировали обоих митрополитов из Архиепископии в резиденцию Верховного комиссара Кипра и ввели военное положение. Опасаясь столкновений между двумя лагерями, митрополит Керинии заявил, что он не примет решения Константинополя об избрании его кандидатуры, если это приведет к народным выступлениям. После этого голосование в Законодательном совете по законопроекту о выборе архиепископа было ускорено.

В апреле 1908 г. греческий вице-консул пишет из Ларнаки в Афины: «Скорее всего, в качестве Архиепископа будет избран митрополит Китиона ... Он будет признан британскими властями и патриархом Александрии, но Вселенская Церковь (Константинопольская патриархия - К. А.) и Иерусалим хотят не признавать его» ${ }^{25}$.

25 мая 1908 г. Законодательным советом Кипра был принят, а Верховным комиссаром утвержден закон о выборах Архиепископа Кипра, вводивший механизм светского избрания главы церкви. В законе строго регламентировался порядок проведения выборов. Кипр был поделен на округа, в каждом из которых, пропорционально населению, избиралось определенное количество представителей, которые непосредственно участвовали в выборе Архиепископа ${ }^{26} .8$ апреля 1909 г. 60 представителей избрали, наконец, новым Архиепископом Кипра митрополита Китиона Кирилла Пападопулоса.

Всего проблеме архиепископского трона на Кипре в период с 1900 по 1909 г. посвящено несколько томов архива МИДа Греции, из материалов которых можно сделать вывод, что церковный кризис на острове имел политический характер, и правительство Греции преследовало в нем свои интересы - избрание митрополита Китиона, сторонника осуществления энозиса, в противовес митрополита Керинии, приверженца политики Константинополя.

Вместе с Архиепископом Кириллом II победу одержало и прогречески настроенное крыло кипрской интеллигенции. 18 марта 1913 г. Законодательное совет Кипра проголосовал за осуществление энозиса. Греческий вице-консул сообщал в свое министерство: «Даже многие не депутаты придерживаются мнения, что остров не должен больше молчать..., должен быть организован референдум на всем острове за энозис» ${ }^{27}$. В то же время греческий дипломат сомневался, что англичане отдадут остров. «Скорее всего, - писал он, - Кипр останется британским приобретением» ${ }^{28}$.

1 октября того же года вице-консул рапортовал в МИД Греции, что на заседании греческой фракции Законодательного совета под председательством Архиепископа до сведения депутатов было доведено мнение короля Греции, что текущий момент - не лучшее время для обсуждения кипрского вопроса и проведения общественных мероприятий, призывающих к энозису, так как у самой Греции сейчас много проблем. На заседании было принято решение прислушаться к этому мнению. Однако, как пишет вице-консул, кипрская пресса не придерживалась этого решения, а наоборот, увеличивала агитацию за энозис, при этом любой, кто его не поддерживал, обвинялся в антипатриотизме ${ }^{29}$. В продолжение затронутой темы в письме от 24 октября вице-консул сообщает, что Архиепископ Кирилл II поддержал правительство Греции в его намерении не торопить решение кипрского вопроса. Вице-консул обвинил главного редактора газеты «Неон Етнос» в том, что тот способствует «разжиганию» энозиса, называя его при этом «хорошим патриотом» ${ }^{30}$.

В октябре 1915 г., в разгар Первой мировой войны, Великобритания делает Греции секретное предложение вступить в войну на стороне стран Антанты в обмен на Кипр. Данное предложение повлекло за собой ответную реакцию киприотов. 8 ноября 1915 г. депутаты Законодательного совета во главе с Архиепископом Кириллом II направили письмо министру колоний Великобритании. «Данное письмо, - отмечали они, - выражает настроение кипрского народа в важный для него исторический момент... Предложение правительства (Be- 
ликобритании - К. А.) соответствует желанию кипрского народа быть свободными и отражает его национальную борьбу» ${ }^{31}$. Копия письма была передана греческому правительству.

Столь желаемое предложение пришлось на период раскола в правящих кругах Греции по вопросу о вступлении страны в войну. Разногласия между премьер-министром Э. Венизелосом и королем Константином I привели к отставке проантантовски настроенного премьер-министра.Для правительства А. Заимиса, сменившего 7 октября 1915 г. на этом посту Э. Венизелоса, Кипр не был основным направлением внешней политики. Афины отклонили предложение Лондона, заявив, что отказ от нейтралитета в обмен на территориальное приобретение не соответствует национальным интересам страны ${ }^{32}$.

Несмотря на решение греческого правительства, Кипрская церковь и местная интеллигенция восприняли этот шаг лишь как временное отступление от курса на энозис, продолжая активно добиваться от британских властей объединения с Грецией.

В 1916 г. умирает Архиепископ Кирилл II Пападопулос. Новым Архиепископом Кипра был избран митрополит Керинии Кирилл Василеос, занявший престол под именем Кирилла III. В том же году с возвращением Э. Венизелоса на пост премьер-министра Греции у киприотов вновь появилась надежда на энозис. В ноябре 1917 г. премьер находился с визитом в Лондоне, где, среди прочих, поднимал вопрос и о Кипре, однако безрезультатно.

После окончания Первой мировой войны, в конце 1918 г., Архиепископ во главе кипрской делегации отправился в Лондон, чтобы передать британскому правительству просьбу кипрских депутатов решить дальнейшую судьбу острова в пользу Греции. В ходе послевоенного международного урегулирования Архиепископ Кипра вел переговоры с премьер-министром Греции о возможности осуществления энозиса и его международного признания. Главной задачей греко-кипрской делегации было успеть решить этот вопрос до подписания мирного договора с Турцией. Следует сказать, что Архиепископ Кирилл, придерживаясь умеренной политики в вопросе энозиса, сомневался в правильности столь настойчивого требования политического объединения Кипра с Грецией, о чем сообщали некоторые представители кипрской делегации в Лондоне $\mathrm{e}^{33}$.

На самом острове в начале 1920 г. прошли выборы депутатов в местные советы городов. Греческий консул писал: «В Никосии, Фамагусте, Пафосе и Керинии победили сторонники Э. Венизелоса, а в Лимасоле и Ларнаке убедительную победу одержали сторонники короля〉 ${ }^{34}$. Данное разделение соответствовало сложившейся политической ситуации на острове, соотношению сил между сторонниками немедленного и постепенного энозиса.

В августе 1920 г. Э. Венизелос лично сообщил Кириллу III о решении Лондона не уступать остров Греции, а 26 октября 1920 г. Министерство по делам колоний официально объявило о решении оставить Кипр под британским управлением ${ }^{35}$.

Отказ Великобритании предоставить острову возможность объединения с Грецией вызвал бурное обсуждение в кипрской прессе. Газета «Киприакос Филакс» 18 августа 1921 г. писала: «Английское правительство не оставило нам и надежды, отклонив просьбу греческих депутатов о союзе с Грецией. Дипломатия бессильна, но кипрский народ не сломлен, в нем горит свеча эллинизма и он будет продолжать борьбу за объединение» ${ }^{36}$.

Накануне выборов в Законодательный совет 1921 г. часть греческих депутатов под председательством Архиепископа Кипрского основали Национальный совет Кипра, который существовал параллельно с Законодательным советом. 25 ноября греческий консул сообщает министру иностранных дел Греции: Архиепископ Кипра обратился к нему с просьбой уведомить правительство в Афинах, что 21-22 ноября в Никосии прошел II Кипрский съезд, члены которого проголосовали «за освобождение острова и за его союз с матерью Грецией» $)^{37} .29$ ноября 1921 г. из Афин в Лондон, где находился с визитом Архиепископ Кирилл III, была направлена срочная телеграмма, сообщавшая, что господин А. Кросфилд получил письмо с Кипра и был расстроен тем, что там происходят антибританские выступления. Англия, заявил он, сейчас является единственным другом греков-киприотов ${ }^{38}$.

3 ноября 1922 г. Национальный совет Кипра под председательством Архиепископа Кипрского и при участии митрополитов Пафского, Китионского, Керинийского, игумена Киккского монастыря и других депутатов проголосовали за энозис, о чем 24 ноября 1922 г.

* А. Кросфилд - член британского парламента, советник премьер-министра Великобритании по Балканам, состоял в дружеских отношениях с Э. Венизелосом. 
было уведомлено греческое правительство ${ }^{39}$. Решение Национального совета было также передано британскому министру по делам колоний.

3 июня 1923 г. состоялся III Кипрский съезд, участники которого обратились с просьбой к английским властям прислать комиссию на остров с целью разобраться в причинах экономического упадка Кипра, а также решить национальный вопрос ${ }^{40}$. Примечательно, однако, что последовавшее 2 июля 1923 г. заседание синода КПЦ в своем решение даже не упоминало о национальном вопросе. Речь шла в основном о новом образовательном законе, принятом британскими властями и лишившем церковь контроля над образованием ${ }^{41}$.

В этот период Великобритания принимала участие в Лозаннской мирной конференции, итогом которой стал мирный договор с Турцией, подписанный 24 июля 1923 г., по которому Анкара признала аннексию Кипра, провозглашенную британским правительством 5 ноября 1914 года ${ }^{42}$.

Несмотря на это, под давлением кипрской интеллигенции 14 октября 1924 г. Архиепископ Кирилл III направил письмо в адрес Верховного комиссара Кипра с целью сообщить британскому правительству о желании киприотов объединиться с Грецией. Ответ Архиепископу, датированный 15 декабря того же года, хотя и был выдержан в дипломатических тонах, но звучал как приговор: «Хочу уведомить Ваше Блаженство, что министр колоний рассмотрел ваш вопрос и поставил его на рассмотрение председателей палаты лордов и палаты общин, и они, в свою очередь, высказывают опасение, что выполнение вашей просьбы невозможно» ${ }^{43}$.

1 мая 1925 г. правительство Великобритании объявило остров Кипр британской колонией. В августе того же года кипрская делегация вновь отправилась в Лондон просить энозиса, однако министр по делам колоний Дж. Г. Томас, возмущенный назойливостью греков-киприотов, дал резкий ответ: «...Вы должны понять четко, что вопрос объединения закрыт и не может быть поднят снова» ${ }^{44}$.

Исходя из материалов греческих консульских органов на Кипре, можно утверждать, что идея энозиса была центральной во взаимоотношениях Кипрской православной церкви и греческого государства. Развитие этой идеи в рассматриваемый период прошло три основных этапа. Первый - 1900-1909 гг. - характеризовался затяжным церковно-политическим расколом на Кипре в связи с отсутствием механизма выбора нового архиепископа и различными подходами к реализации энозиса претендентов на архиепископский престол - митрополитов Китиона и Керинии. С избранием в 1909 г. Архиепископом Кипра решительного сторонника энозиса митрополита Китиона начинается новый этап. Политическая элита Греции на тот момент оказалась расколотой на сторонников и противников вступления страны в Первую мировую войну. Осенью 1915 г. греческое правительство А. Заимиса отказалось от предложения Великобритании присоединиться к Антанте в обмен на Кипр, упустив тем самым реальный шанс приобрести остров дипломатическим путем. Третий этап борьбы за энозис КПЦ и греческого руководства был связан с попыткой умеренным сторонником энозиса Архиепископом Кириллом III добиться решения национального вопроса в ходе мирных переговоров после окончания Первой мировой войны. Однако Великобритания отказалась уступать остров грекам, закрепив его аннексию в Лозанском мирном договоре, официально объявив Кипр британской колонией в 1925 г. Таким образом, совместные попытки КПЦ и греческого правительства добиться энозиса на протяжении 1900-1925 гг. не увенчались успехом.

${ }^{1}$ Hill G. A history of Cyprus. - V. IV. The Ottoman Province. The British Colony 1571-1948. Cambridge, 1952. - P. 488-568.

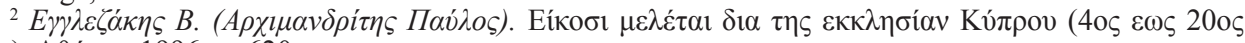

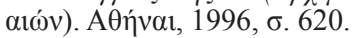

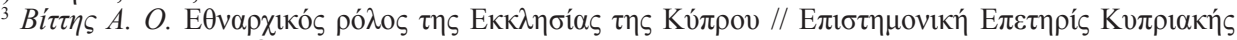

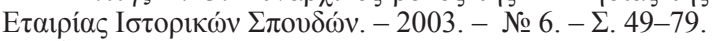

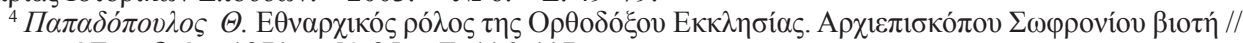

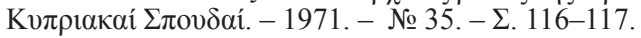

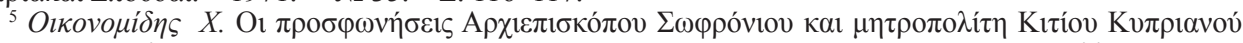

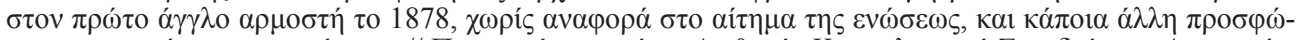

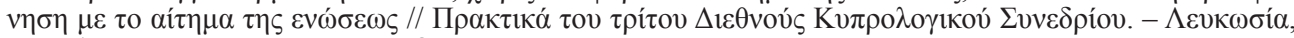

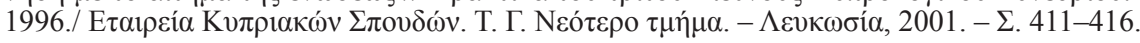


${ }^{6}$ Varnava A., Michael M. N. The Archbishops of Cyprus in the Modern Age: The Changing Role of the Archbishop-Ethnarch, their Identities and Politics. - Cambridge, 2013. - $331 \mathrm{p}$.

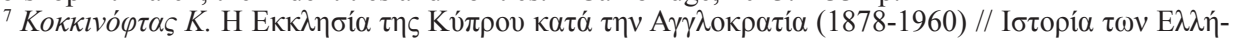

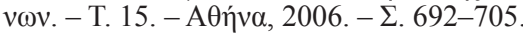

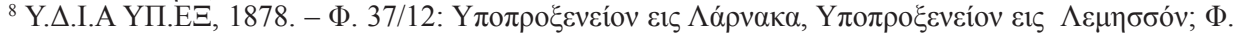

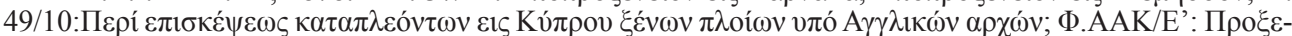

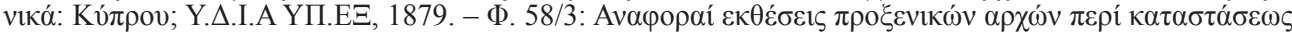

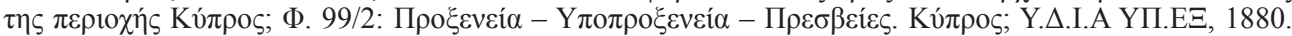

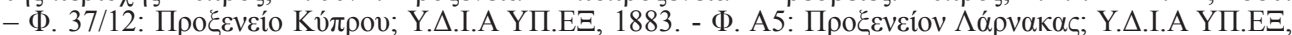

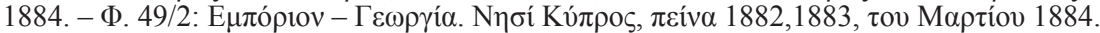

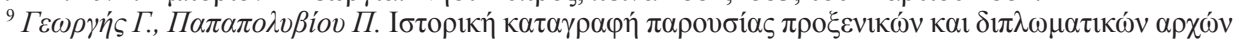

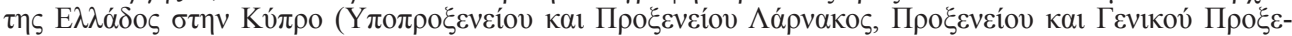

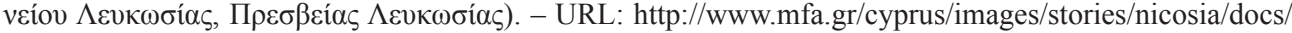
istoria arxis.pdf (дата обращения: 18.10.2015)

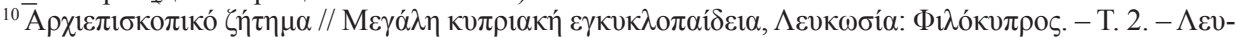
$\kappa \omega \sigma i ́ \alpha, 1985 .-\Sigma .348-350$.

${ }_{11}^{11}$ Там же.

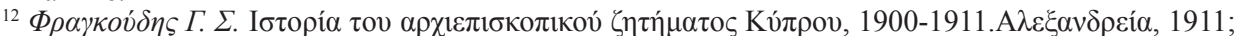

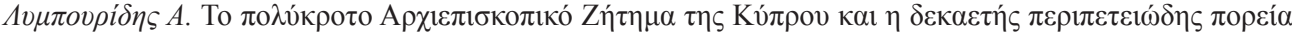

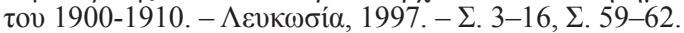

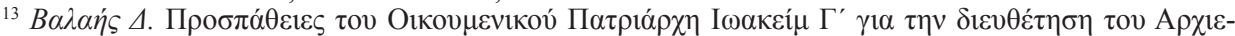

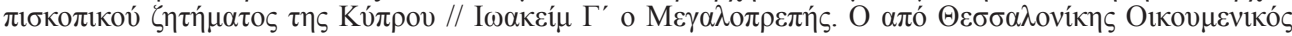

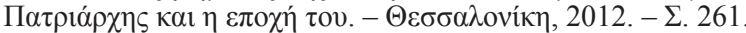

${ }_{14}$ Там же.

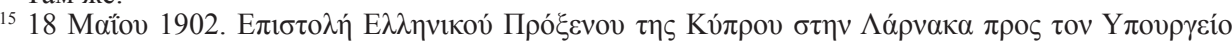

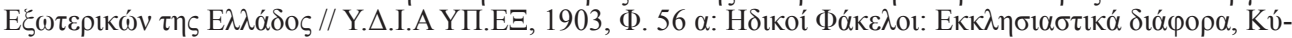

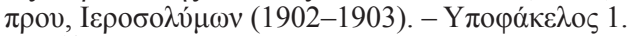

16 Там же.

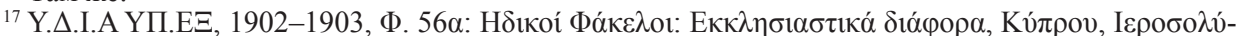

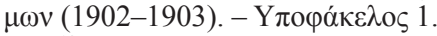

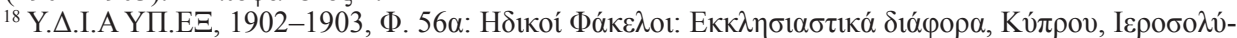

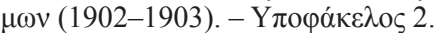

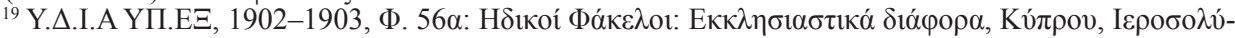

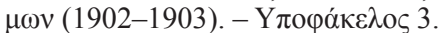

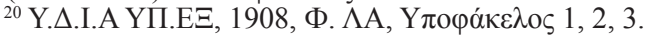

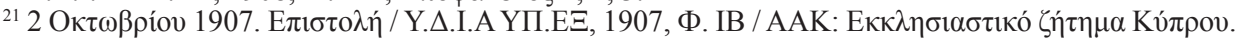

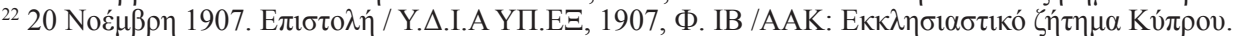

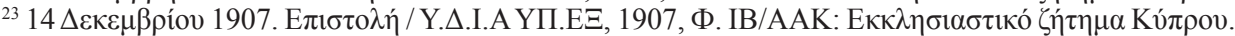

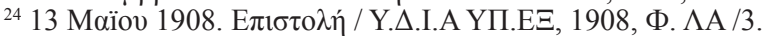

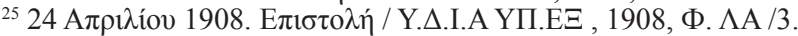

${ }^{26}$ The Cyprus gazette (supplement). - 1908. - 25 May.

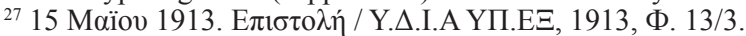

${ }^{28}$ Там же.

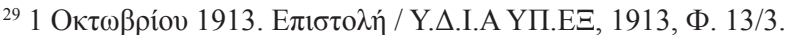

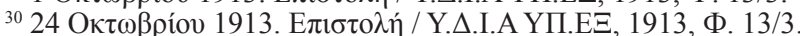

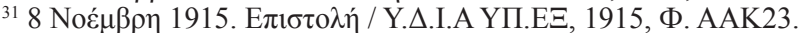

${ }^{32}$ Hill G. A history of Cyprus. - V. IV. The Ottoman Province. The British Colony 1571-1948. Cambridge, 1952. - P. 522-523

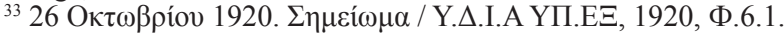

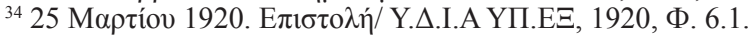

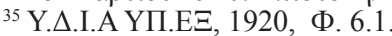

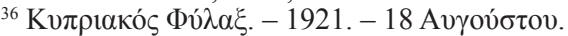

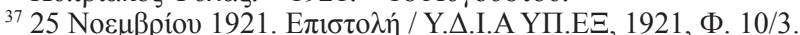

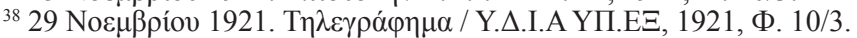

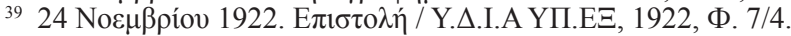

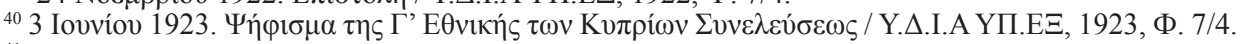

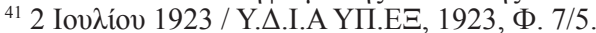

${ }^{42}$ The Convention Respecting the Regime of the Straits and Other Instruments Signed at Lausanne, 24 July 1923 / The Cyprus issue. A documentary history, 1878-2007. - London-New York, 2007. - P. 7.

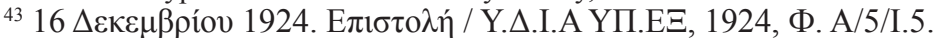

${ }^{44} 14$ Av 